This is the accepted manuscript of the article, which has been published in Global Society. 2017, 31(2), 220-244. http://dx.doi.org/10.1080/13600826.2016.1274963

\title{
THE PSYCHOLOGICAL DIMENSION OF RUSSIAN FOREIGN POLICY: PUTIN AND THE ANNEXATION OF CRIMEA
}

\author{
Tuomas Forsberg - Christer Pursiainen \\ University of Tampere - The Arctic University of Norway (Tromsø)
}

\begin{abstract}
This article contributes to the growing scholarly literature endeavouring to explain Russia's annexation of the Crimean Peninsula in 2014. While much of the debate relies on the grand theories of International Relations such as realism, liberalism, or constructivism, this article approaches the puzzle from a psychological point of view and discusses several middle-range theories within this genre. These theories are examined sympathetically but critically, spelling out the added value they might have in elucidating Russian foreign policy, while also considering the methodological limitations in producing plausible explanations. Moreover, the article strives to overcome the traditional juxtaposition between the idea of rationality as a standard account of agency, and various psychological interpretations. Obvious methodological problems notwithstanding, the article concludes that cognitive and psychological features - such as the possibility of groupthink, assessment of prospects, operational codes and belief systems, personality characteristics, and emotions - can be applied to the Russian case and they can all explain Russia's higher willingness to take risks in the context of the Ukrainian crisis. In that way they can provide with partial explanations, and indeed are important elements of our understanding of Russian foreign policy in general and the Crimean case in particular.
\end{abstract}

Keywords: Russia; Ukraine; Putin; Crimea; rationality; groupthink; risk-taking; prospect theory; operational code; personality; emotions

Contact: Tuomas Forsberg, School of Management, 33014 University of Tampere, email: tuomas.forsberg@uta.fi

Acknowledgements: We would like to thank Academy of Finland Centre of Excellence on Choices of Russian Modernisation (grant nr. 284664) for partial support of research leading to this article. We are also grateful to the editors of this special issue as well as the anonymous reviewers for their comments.

\section{About the Authors:}

Tuomas Forsberg is Professor of International Relations at the University of Tampere. He is also deputy director of the Academy of Finland Centre of Excellence on Choices of Russian Modernisation (2012-17) at the Aleksanteri Institute of the University of Helsinki. His research has dealt primarily with European security issues, focusing on the EU, Germany, Russia and Northern Europe.

Christer Pursiainen is Professor of Societal Security at the Artic University of Norway (Troms $\varnothing$ ). His scholarly publications focus on such themes as crisis management, international relations theory, and Soviet / Russian history and politics, published in different countries and in several languages. 


\section{Introduction}

Russia's intervention in and subsequent annexation of the Crimean Peninsula in 2014, and the ensuing developments in Ukraine and Russia-West relations, provides a contemporary challenge not only for policymaking but also for the foreign policy scholarly community. What explains Russia's decision-making and behaviour? ${ }^{1}$ While full-fledged explanations or interpretations, based on detailed empirical investigation, have yet to emerge, we are not short of theoretically grounded post-factum analyses. Typically, many familiar explanations draw on mainstream International Relations (IR) grand theories - realism, liberalism, and constructivism - and are in one way or another rooted in the wider context of Russia-West relations. Yet, the key role of Vladimir Putin as President of Russia would call instead for psychological approaches traditionally at the heart of Foreign Policy Analysis (FPA). However, such explanations are difficult to present with any certainty due to the lack of transparency in Russian decision-making. Yet, the paradox is that the less we have access to the actual decision-making process, the more important the psychological dimension might be, at least potentially. ${ }^{2}$

While Russia's behaviour in the Ukrainian crisis surprised the policy community, it is also clear that an overwhelming majority of scholars of international relations and Russian politics, irrespective of their theoretical orientation, failed in their forecasts. In a poll conducted among 905 American researchers about a week before Russia invaded Crimea, only 14 per cent of those interviewed responded affirmatively to a question on whether Russia would interfere militarily in Ukrainian affairs. ${ }^{3}$ The fact that all IR schools failed to anticipate Russia's behaviour but still provide the most well-known explanations of the case reminds us that concepts such as national interest or identity are so vague that one can always use them to

\footnotetext{
${ }^{1}$ See e.g. Elizabeth Wood, William Pomeranz, E. Wayne Merry and Maxim Trudolyubov, Roots of Russia's War in Ukraine (Washington D.C.: Woodrow Wilson Center Press, 2016); Elias Götz, 'Putin, the State and War: The Causes of Russia's Near Abroad Assertion Revisited', International Studies Review, 2016, early view. ${ }^{2}$ Cf. James Rosenau, 'Pre-theories and Theories of Foreign Policy' by James Rosenau, in R. B. Farrell (ed.) Approaches in Comparative and International Politics (Evanston, IL: Northwestern University Press, 1966), pp. 27-92.

${ }^{3}$ Erik Voeten, "Who predicted Russia's military intervention?" Washington Post (March 12, 2014), available at: $<$ http://www.washingtonpost.com/blogs/monkey-cage/wp/2014/03/12/who-predicted-russias-militaryintervention-2/>; Daniel Maliniak, Susan Peterson, Ryan Powers and Michael J. Tierney, "Snap Poll: The View from the Ivory Tower", Foreign Policy (March 7, 2014), available at:

$\langle$ http://www.foreignpolicy.com/articles/2014/03/07/snap_poll_the_view_from_the_ivory_tower_syria_defense_ ukraine_russia > and the detailed results available: <http://www.wm.edu/offices/itpir/trip/snap-polls/snap-pollresults-march-2014/index.php>.
} 
retrospectively explain an event which was regarded as unlikely beforehand on the basis of the very same concepts.

Indeed, there is already a plethora of scholarly explanations reflecting the common theoretical approaches to Russian foreign policy that account for Russia's policy in the Ukraine conflict and the decision to annex Crimea. Perhaps the most famous is John Mearsheimer's offensive structural realism. ${ }^{4} \mathrm{He}$ argues that Russia's actions in Ukraine should be seen as a self-evident reaction to the external context, that is, to the West's aggressive grand strategy, which exploits colour revolutions in Russia's neighbourhood as one of the weapons in the struggle for power. Those who agree with this view see that it is all about geopolitics: Russia's primary objective is to keep Ukraine out of foreign military alliances and geopolitical blocs. ${ }^{5}$ There is some variation of this general theme: for Daniel Treisman, for example, the seizure of Crimea was an improvised solution to secure Russia's possession of the Sevastopol naval base. ${ }^{6}$ A more formalistic approach towards describing this strategic interaction has been presented by Richard Ericson and Lester Zeager in pure game-theoretic terms, using the so-called theory of moves. The idea is to derive the equilibrium, or ultimate outcome under various assumptions about Western and Russian preferences over outcomes. With regard to the endgame, the theory concludes that "incomplete information on preferences prevents derivation of a unique prediction of the outcome of the crisis, but the analysis enables us to substantially narrow the range of possibilities". ${ }^{7}$ The example shows that sophisticated models of different scenarios can be developed on the basis of rational choice, but ultimately such models also face the challenge of empirical data in terms of explanation. Michael McFaul, representing the liberal school of thought, claims in turn that the reasons for Russia's behaviour lie in Russia's domestic politics; Putin reacted to the homegrown threat of a colour revolution and created an external crisis to make it possible to enhance the domestic pressure against the opposition and to rally the nation around the flag. ${ }^{8}$ Robert Legvold, whose thinking can be associated with the

\footnotetext{
${ }^{4}$ John Mearsheimer, "Why the Ukraine Crisis is the West's Fault. The Liberal Delusions That Provoked Putin" Foreign Affairs Online (September/October 2014), available at: $\langle$ http://www.foreignaffairs.com/articles/141769/john-j-mearsheimer/why-the-ukraine-crisis-is-the-wests-fault $>$. 5 Elias Götz, "It's geopolitics, stupid: explaining Russia’s Ukraine policy", Global Affairs, 1:1 (2015), pp. 3-10. ${ }^{6}$ Daniel Treisman, 'Why Putin Took Crimea: The Gambler in the Kremlin', Foreign Affairs Vol 95, No. 3, 2016, pp. 47-54.

${ }^{7}$ Richard E. Ericson and Lester A. Zeager, "Ukraine Crisis 2014: A Study of RussianWestern Strategic Interaction", Peace Econ. Peace Sci. Pub. Pol. 21(2) (2015), pp. 153-190.

${ }^{8}$ Michael McFaul, Stephen Sestanovich and John J. Mearsheimer, "Faulty Powers: Who Started the Ukraine Crisis?", Foreign Affairs Online (November/December 2014), available at: <http://www.foreignaffairs.com/articles/142260/michael-mcfaul-stephen-sestanovich-john-jmearsheimer/faulty-powers>.
} 
constructivist school, argues that the Cold War's lesson for contemporary Russia and the US is that it is the interaction between the two sides, rather than the actions of only one side, that creates the spiral in tensions. ${ }^{9}$ This can be understood as an external dimension of identity politics. Ted Hopf has argued how partly because of external iinteraction Russian national identity discours4es changed so that the annexation of Crimea became both thinkable and natural by $2014 .{ }^{10}$ A more internal identity dimension is what some analysts see as the Russian use of "bio-politics", that is, claiming to defend the interests of "compatriots" in the "Russian world". ${ }^{11}$ These theories are not necessarily in direct competition with each other. Andrei Tsygankov, for example, suggests that both interests and values explain Russia's behaviour in the Ukrainian crisis. ${ }^{12}$ Roy Allison combines the above explanations, considering that one has to understand the geopolitics, identity and domestic political influences in order to explain Russia's conduct in this case. ${ }^{13}$ Elias Götz also concludes his survey of theories attempting to explain Russia's assertive policy in the "near abroad" by warning against mono-causal approaches and stating that future research should develop different synthetic explanations. ${ }^{14}$

We will contribute to this debate by advancing a set of psychological approaches ${ }^{15}$. This should not be seen as a case for mono-causal explanations but as an attempt to construct theoretically sustained psychological explanations, to assess them against the background of available evidence and to discuss their limitations. Such theories can at best explain only an aspect of Russian foreign policy, but without spelling them out first, they cannot be integrated and synthesised with other theories. Psychological theories have always been part of the tradition of Soviet / Russian foreign policy research but paradoxically in the present context these theories have remained marginal and underdeveloped. ${ }^{16}$ Yet, the need is evident since there has also been a remarkable surge in literature focusing on Putin as a person (and it would be a small

\footnotetext{
${ }^{9}$ Robert Legvold, "Managing the New Cold War: What Moscow and Washington Can Learn From the Last One", Foreign Affairs (July/August 2014), pp. 74-84.

10 Ted hopf, "Crimea is Ours": A Discursive History', International Relations Vol. 30 No. 2 (2016) 227-255.

${ }^{11}$ Philipp Casula, “The Road to Crimea: Putin's Foreign Policy Between Reason of State, Sovereignty and BioPolitics", Russian Analytical Digest No. 148 (2 May 2014), pp. 2-6.

12 Andrei Tsygankov, “Vladimir Putin's Last Stand: the Sources of Russia's Ukraine Policy”, Post-Soviet Affairs, Vol. 31, No 4 (2015) pp. 279-303.

${ }^{13}$ Roy Allison, "Russian 'deniable' intervention in Ukraine: how and why Russia broke the rules", International Affairs Vol. 90, No. 6 (2014), pp. 1255-1297.

${ }^{14}$ Götz, Putin, the State and War, p. 21.

${ }^{15}$ For a parallel contribution, see Tor Bukkvoll, 'Why Putin Went to War: Ideology, Interests and Decisionmaking in the Russian use of Force in Crimea and Donbas', Contemporary Politics, Vol 22, No. 3, (2016), pp. 267-282.

${ }^{16}$ See e.g. Alexander Sergunin, Explaining Russian Foreign Policy Behavior : Theory and Practice (Stuttgart: ibidem).
} 
wonder if this were not the case, given that Putin was named by Forbes the most powerful man in the world in 2016). ${ }^{17}$ Although we should not exaggerate the psychological perspective let alone make it pre-eminent, we need to account for the psychological aspects of agency. Our attitude towards these approaches is sympathetic but critical at the same time. This new semiacademic branch of "Putinology", reminiscent of the old "Kremlinological" tradition in that much of it is based on the art of second-guessing the inner dynamics of an opaque system, cannot be entirely dismissed but it has not evolved in a cumulative and integrative manner with the aim of theory building or development. ${ }^{18}$ Such theories exist, however, and could be utilised more systematically. Unlike IR grand theories, psychological approaches can be located within the middle-range theorizing typical of FPA; they are partly but not entirely individual-level explanations focusing on a single decision-maker since they can point to both general situational psychological tendencies as well as group-level psychological dynamics. These approaches rarely claim to offer all-encompassing, comprehensive, or sufficient explanations for any decision, but, as we argue, they can provide partial explanations that are nevertheless crucial for understanding foreign policy decision-making in cases such as Russia's intervention in Crimea.

We will home in on these approaches in order to examine how they could contribute to the explanation of Russia's decision-making and behaviour in the context of the Ukrainian crisis of 2014. In so doing, we will also draw a historical-theoretical picture, and review how these approaches have previously been applied to the study of Russian foreign policy in particular. We are most willing to admit that the empirical evidence related to psychological theories is often speculative and we may never find any "final proof", but attempts to apply them can perhaps better be seen as "hoop tests" that make one theory plausible while not excluding others. ${ }^{19}$ We cannot bring decision-makers to a test laboratory, and nor can we reconstruct the real decision-making situations and measure the cognitive and other psychological processes directly; at the same time, we do not have any final proof of the superiority of a rational choice theory either. Our argument, however, is that obvious methodological problems

\footnotetext{
${ }^{17}$ Fiona Hill and Clifford G. Gaddy, Mr. Putin: Operative in the Kremlin. 2nd Ed. (Washington D.C.: Brookings Institution Press, 2015); Anna Arutunyan, The Putin Mystique: Inside Russia's Power Cult (Newbold on Stour: Skyscraper, 2014); Steven Lee Myers, The New Tsar: The Rise and Reign of Vladimir Putin (New York: Alfred Knopf, 2015). See also Fiona Hill, 'Putin: The One-Man Show the West Doesn't Understand', Bulletin of the Atomic Scientists Vol. 72, no 3, 2016, pp. 140-144.

${ }^{18}$ See e.g. Leon Aron, "Putinology", The American Interest, Vol. 11, No. 1, (July 2015), available at: $\langle$ http://www.the-american-interest.com/2015/07/30/putinology/>. For research on Gorbachev and Yeltsin, see e.g. George Breslauer, Gorbachev and Yeltsin as Leaders (Cambridge: Cambridge University Press 2002). ${ }^{19}$ Andrew Bennett and Jeffrey Checkel, Process-Tracing (Cambridge: Cambridge University Press 2016).
} 
notwithstanding, psychological approaches - such as groupthink, risk-taking patterns, operational codes, personality characteristics, and emotions - will not only complement but are indeed necessary elements of any in-depth discussion and understanding of Russian foreign policy in general and the Crimean case in particular. ${ }^{20}$ While these approaches are sometimes seen as demonizing Putin, in essence, they do exactly the opposite when treating Putin as a normal human person potentially following general behavioural patterns in decision-making.

\section{Beyond the juxtaposition of rationality and psychology}

The question of whether Putin is acting rationally or not has been posed in the context of the crisis in Ukraine. ${ }^{21}$ As remarked by Mark Galeotti and Andrew S. Bowen, Russia was by no means forced to invade Crimea: "After all, the annexation of Crimea, by any rational calculation, did not make sense. Russia already had immense influence on the peninsula, but without the need to subsidize it, as Ukraine had. [...] The Russian Black Sea Fleet's position in the Crimean seaport of Sevastopol was secure until 2042". ${ }^{22}$ In any case, even if the choice is seen as rational, Russia was willing to take high risks when violating key norms of international law and launching a military campaign.

Such a question - rational or not - often assumes that we can juxtapose rationality and psychology, but this is often impossible. To begin with, there are several types of rationality. A strict methodological definition of rationality - as proposed by positivist science - is that a theory should not treat persons as individuals with their own psychology and preferences, but rather it seeks to turn individual behaviour into that conducted by anybody in a similar situation. ${ }^{23}$ Mainstream political realism has turned this into a normative claim that the pursuit of national interest, defined as power, should guide the foreign policy of a state if it desires to be successful and survive. ${ }^{24}$ The mere notion of instrumental rationality, however, does not

\footnotetext{
${ }^{20}$ As Elizabeth Wood suggests, "Russian actions may combine the rational and the irrational, as well as shortand long-term considerations", in Wood, Pomeranz, Merry and Trudolyubov, op. cit., p. 19.

${ }^{21}$ Alexander Motyl, "Is Putin Rational?" Foreign Affairs Online (18 March, 2014), available at: <http://www.foreignaffairs.com/articles/141039/alexander-j-motyl/is-putin-rational>. See also Rajan Menon, "Putin's Rational Choices", Foreign Affairs Online (29 February, 2016), available at: <https://www.foreignaffairs.com/articles/russian-federation/2016-02-29/putins-rational-choices>.

${ }^{22}$ Mark Galeotti and Andrew S. Bowen, "Putin's Empire of the Mind: How Russia’s president morphed from realist to ideologue - and what he'll do next", Foreign Policy (April 21, 2014), available at: <http://foreignpolicy.com/2014/04/21/putins-empire-of-the-mind/>.

${ }^{23}$ Karl Popper, The Myth of Framework: In Defence of Science and Rationality (London: Routledge, 1994), p. 168.

${ }^{24}$ Hans J. Morgenthau, Politics Among Nations: The Struggle for Power and Peace (New York: Alfred A. Kopf, 1955).
} 
predict anything about what an actor should want in a choice situation. Rationality is merely understood as a process of gathering sufficient information about costs and benefits and then choosing the option more likely to lead to a better outcome, according to the pre-existing desires among the available alternatives. ${ }^{25}$ Bounded rationality, in turn, is already a step towards taking into account psychological factors, as it emphasises the improbability of optimal choice in most cases. The decision-maker is, rather, a "satisfier": one seeking a satisfactory solution based on imperfect information and in the presence of cognitive biases. Thus the decision-maker stops considering alternatives when he thinks that he has found a satisfactory solution, even if it were not the optimal. ${ }^{26}$

There are basically three ways to understand the relationship between rationality and psychology with regard to decision-making. The first has already been alluded to: psychological approaches are often seen as an antithesis to rational choice methodology. These two approaches are understood as mutually exclusive. In this understanding, there is also an implicit or explicit normative juxtaposition between a rational decision-maker and someone whose decision-making is seemingly negatively affected by psychological attributes, such as stress, ideological prejudices, or emotions. The second approach regards the degree of rationality vs. psychology as some kind of continuum. Indeed, psychological theories dealing with decision-making vary in how much they overlap with instrumental or bounded rationality. While human beings strive mostly for some kind of rationality in their actions, psychological approaches, however, discuss the limits of rationality and reveal some features in human behaviour which, from a very strict rational choice approach, may appear as anomalies. The point of psychological approaches, therefore, is that they normalize these anomalies. A third, and more recent approach assumes that it is more fruitful to understand rationality as a part of human psychology, rather than seeing rationality and psychology as opposite components. Psychological and, above all, neurological research has made great strides in recent years in understanding the importance of emotions, particularly during decision-making. In this latest research, what is noteworthy is the realization that emotions are not necessarily the opposite of rationality, arising as impulses in the mind only in extreme situations. Rather, emotions are essential to human rationality and are always present in decision-making, since rational

\footnotetext{
25 Jon Elster, Rational Choice (Oxford: Basil Blackwell, 1986).

${ }^{26}$ Herbert A. Simon, Administrative Behavior (New York: Free Press, 1947).
} 
information processing and emotion in the human brain are physically and functionally much more closely integrated than previously thought. ${ }^{27}$

Within the set of psychological approaches - both cognitive and affective - that we will discuss below, usually one or another of the above arguments is in the background, which makes these approaches themselves somewhat rival explanations vis-à-vis each other. At the same time, however, they form a toolbox of useful theoretical perspectives, relying on group dynamics, personal characteristics and situational factors that are typically omitted in the IR grand theories.

\section{Groupthink in the Kremlin?}

Groupthink has long featured among the most-cited psychological theories in foreign policy analysis. Irving L. Janis presented the concept to explain why a small group of decisionmakers, no matter how astute, can reach not only suboptimal but clearly irrational decisions on the most important issues. ${ }^{28}$ One of his case studies was the disastrous Korean war, in the context of which American foreign policy decision-making was characterized by an almost naive harmony, mutual admiration and flattery. According to the theory, the reason for false decisions may be that, in certain circumstances, the decision-makers do not strive for the best solution but for a consensus decision, whereby they omit even clear facts and do not allow any contradictory information and opinions to interfere with the group dynamics.

It is interesting to consider Russia's decision-making in the Crimean question from this perspective. What do we know about the decision-making unit and the circumstances? An article that comes closest to revealing something about this particular decision-making situation appeared in the New York Times on 7 March 2014, that is, dated less than a week after Russian troops seized control of the peninsula, and about a month before Russia acknowledged it

\footnotetext{
${ }^{27}$ Andrew Ross, Mixed Emotions: Beyond Fear and Hatred in International Conflict (Chicago: The University of Chicago Press, 2014); Jonathan Mercer, "Emotional Beliefs", International Organization, Vol. 64, No 1 (2010), pp. 1-31; Jonathan Mercer "Rationality and Psychology in International Politics", International Organization, Vol. 59, No 1 (2005), pp. 77-106; Rose McDermott, "The Feeling of Rationality: The Meaning of Neuroscientific Advances for Political Science", Perspectives on Politics, Vol. 2, No 4 (2004), pp. 691-706; M. Goldgeier and P.E. Tetlock, "Psychology and International Relations Theory", Annual Review of Political Science, Vol. 4 (2001), pp. 67-92.

${ }^{28}$ Irving Janis, Groupthink: Psychological Studies of Policy Decisions and Fiascoes, 2nd edition (Boston: Wadsworth Cengage Learning, 1972/1982).
} 
publically. ${ }^{29}$ The article states that the decision to invade Crimea was taken very rashly on either February 25 or 26: "The group, the officials and analysts said, included Sergei B. Ivanov, Mr. Putin's chief of staff; Nikolai P. Patrushev, the secretary of the security council; and Aleksandr V. Bortnikov, the director of the Federal Security Service. All are veterans of the K.G.B. [...]". Only later was the decision communicated to the Security Council and the Foreign Ministry. ${ }^{30}$

This information, from corridor sources of "officials and analysts", was subsequently circulated in other analyses and became the more or less accepted version of events. ${ }^{31}$ Putin's own statements in a Russian TV documentary at the beginning of 2015, now widely available in social media, to some extent confirm this account. According to Putin, however, the decision was made during the night between February 22 and 23. In this interview, Putin frames the decision as being related to planning the rescue of the deposed Ukrainian president, Viktor Yanukovych, but it is not quite clear how this actually made the Crimean intervention necessary. Furthermore, he recollects that besides himself there were four colleagues in the meeting. Putin does not reveal the names of those four colleagues, but it is probable that they included the three mentioned above and Defence Minister Sergey Shoygu, who was allegedly present. In any case, Putin states that he himself took the initiative and ordered his colleagues to prepare the takeover of Crimea. Yet one gets the impression that the annexation of Crimea was not discussed until the very end of the meeting, implying that Putin would have made this decision rather spontaneously before the meeting wrapped up: "We ended at about seven in the morning. When we were parting, I said to my colleagues: we must start working on returning Crimea to Russia". ${ }^{32}$ This statement, of course, contradicts the statements made by Putin after the intervention, to the effect that Russia had not planned anything in advance, but had just reacted to the will of the Crimean people, expressed in a (post factum) referendum. ${ }^{33}$

\footnotetext{
${ }^{29}$ Steven Lee Myers, "Russia's Move Into Ukraine Said to Be Born in Shadows", The New York Times (March 7, 2014).

${ }^{30}$ Ibid.

${ }^{31}$ Andrew C. Kuchins "Is Putin Having a Brezhnev Moment?” Politico (March 11, 2014), available at: <http://www.politico.com/magazine/story/2014/03/putin-brezhnev-moment-crimea104547.html\#ixzz3PdJ3Utgqhttp://www.politico.com/magazine/story/2014/03/putin-brezhnev-moment-crimea104547.html\#.VMIL703wsdV>.

32 "Vladimir Putin describes secret meeting when Russia decided to seize Crimea", The Guardian (9 March, 2015), available at: <http://www.theguardian.com/world/2015/mar/09/vladimir-putin-describes-secret-meetingwhen-russia-decided-to-seize-crimea>.

33 “'Krymnash': kak za god menjalas' lozh' Putina ob anneksii poluostrova", Obozrevatel (10 March, 2015), available at: <http://obozrevatel.com/politics/20654-kryimnash-kak-za-god-menyalas-lozh-putina-ob-anneksiipoluostrova.htm>.
} 
There is also some evidence that the idea of annexing Crimea would have been expressed one or two weeks earlier in February 2014 by a powerful business group, in a memorandum presented to Putin. ${ }^{34}$ Others have remarked that the idea was seriously considered in the Kremlin as early as December 2013. The question would have been raised by the chairman of the Crimean Parliament, Dmitry Konstantinov, when he visited Moscow and met with Patrushev, who was positively surprised. Moreover, the possibility of annexing Crimea had been discussed as a principal option in the Kremlin back in $2008 .{ }^{35}$

Nevertheless, the wider narratives of Russia's foreign-policy formulation point to the concentration of power and the diminishing role of outside influence. It has been proposed that when Putin first came to power in 1999/2000, he "listened to a range of opinions", "being the arbiter brokering consensus among various clans and interests", whereas today his "circle of allies and advisors has shrunk to those who only share his exact ideas". As a consequence, "[S]ober technocrats such as Foreign Minister Sergei Lavrov and Defence Minister Sergei Shoygu played a seemingly marginal role in the decision-making over Crimea and were expected simply to execute the orders from the top". ${ }^{36}$ Although it has been claimed that Shoygu was hesitant with regard to the military intervention in Ukraine, he did not voice his arguments forcefully. ${ }^{37}$

If these views are correct, we can conclude that the decision-making unit consisted of likeminded "hawks" belonging to the "siloviks", whereas all those usually regarded as representing a more "liberal" wing were missing. The group was obviously controlled by a strong leader, but all the elements conducive to groupthink emerging were present. ${ }^{38}$ According to the groupthink theory, such a constellation of the decision-making unit, with very little space for an open and rational search for alternatives, creates a tendency to influence the decisionmaking towards increased risk-taking.

\footnotetext{
34 "Predstavljaetsja pravil'nym iniciirovat' prisoedinenie vostochnyh oblastej Ukrainy k Rossii", Novaja Gazeta (24 February, 2015), available at: < http://www.novayagazeta.ru/politics/67389.html $>$.

${ }^{35}$ M. Zygar, Vsja kremlevskaja rat: Kratkaja istorija sovremennoj Rossii (Moscow: Ozon.ru 2016).

${ }^{36}$ Galeotti and Bowen, op. cit.

${ }^{37}$ Zygar, Vsja kremlevskaja rat.

${ }^{38}$ For the same argument, see Kimberly Marten, "Putin's Choices: Explaining Russian Foreign Policy and Intervention in Ukraine", The Washington Quarterly 38:2 (2015), pp. 189-204.
} 
It also seems that the consequences of the decisions were not considered in detail, as one might expect from a rational decision-maker. While it must have been obvious that the annexation would place a direct financial burden on Russia's state budget, this issue was not investigated: "If we speak about whether the Ministry of Finance was asked about how much it would cost", said Russian Deputy Finance Minister Tatyana Nesterenko a year later, "I can say no - nobody asked. But to answer the question whether the price is appropriate or not, we need to know a lot [more]. The level of our competence is not enough to answer this question, and we don't know what information is possessed by the [leader] of our country. [...] Such decisions can only be taken by one person. I know the president and I can say that he does not make decisions lightly. But, in fairness, it was also unexpected for all of us". 39

While we cannot know for sure the extent to which groupthink played a role in the decisionmaking regarding the annexation of Crimea, it is clear that alternative explanations underpinned by realism, liberalism or constructivism are neither more informed nor more rooted in any "hard evidence" of the actual nature of the decision-making. It is not beyond the realms of possibility that a future study on political history might advance more such features of the decision-making situation that will retrospectively support the groupthink argument, but in order for that to happen, it is important that the theoretical plausibility of groupthink to be presented first.

\section{Framing the choice as avoiding losses?}

Another psychological theory that might explain the Kremlin's propensity to take risks in the Ukraine conflict is prospect theory. The theory was developed by Daniel Kahneman and Amos Tversky in the 1970s, when they investigated why the behaviour of people so often differs from what would be expected to be rational. Prospect theory claims that people are generally riskaverse in choices involving gains and more likely to be risk-seekers in choices involving losses. As many choice situations can be framed in terms of both gains and losses, this notion challenges the fundamentals of rationality; instead of choosing on the basis of the outcome's utility value, the way the choice's starting point is framed affects the preference order. ${ }^{40}$

\footnotetext{
39 "Decision to annex Crimea 'taken by Putin personally", Unian Information Agency (5 March, 2015), available at: 〈http://www.unian.info/politics/1052109-decision-to-annex-crimea-taken-by-putinpersonally.html $>$.

${ }^{40}$ Daniel Kahneman and Amos Tversky, "Prospect Theory: An Analysis of Decision Under Risk", Econometrica, Vol. 47 (1979), pp. 263-291.
} 
In international relations, prospect theory has been used to explain why politicians are sometimes ready to take overwhelming risks against the odds. ${ }^{41}$ While Russian foreign policy in the Ukraine crisis has not been analysed in academic articles in terms of prospect theory, the latter has been utilised in journalistic accounts. ${ }^{42}$ The argument is that Putin had interpreted the political developments in Ukraine in early 2014 as a loss of the preferred status quo. Therefore he was ready to take many risks, most notably by invading Crimea, and subsequently in starting to support the separatist fighting in Eastern Ukraine. In other words, it was actually weakness, not strength that led Russia to invade Crimea.

While prospect theory is usually situated within psychological approaches, a specific feature of this approach is that it does not differentiate between individuals but anticipates on the basis of average behaviour, at least in repeated or large n contexts, based on a different rationality that pure rational choice based on utility values would suggest. It has been found that prospect theory generally holds across different cultures, although there are some significant exceptions. However, the theory does not contain any clear statement about how the framing exactly happens, that is, what the reference point is for gains and losses. The theory, in this sense, has problems similar to those in rational choice theory. In retrospect, one can define the reference point from the choices, but not independently from the materialized action. In a sense, the argument then becomes circular.

However, combined with prevailing definitions of Russia's national interest or identity, or individual decision-maker's belief system, one might make a fair estimation of the reference points of Russian foreign policy, and then draw a conclusion about Russia's risk-taking behaviour. This type of tailored approach would consequently individualise or contextualise the otherwise general notion of prospect theory for a certain foreign policy situation and actor. Yet, it seems rather commonplace to argue that Ukraine's tightening relationship with the EU in the form of the Association Agreement was framed as a loss, while Ukraine's entry to the

\footnotetext{
${ }^{41}$ Jack Levy, "Prospect Theory and International Relations: Theoretical Applications and Analytical Problems", Political Psychology, Vol. 13, No 2 (1992), pp. 283-310; Jonathan Mercer, "Prospect Theory and Political Science”, Annual Review of Political Science, Vol. 8, No 1 (2005), pp. 1-21.

42 Sarah Sloat, “An Interesting Theory That Could Explain Vladimir Putin's Risky Behavior”, New Republic (March 19, 2014), available at: <http://www.newrepublic.com/article/117077/vladimir-putins-risky-behaviorcould-be-explained-prospect-theory>; Prospect theory and Crimea, February 9, 2015. <https://irrussianality.wordpress.com/2015/02/09/prospect-theory-and-crimea/>; Military Conflict Decisions: Why Weakness Leads To Aggression (March 10, 2015), available at: <http://www.npr.org/2014/03/10/288492921/military-conflict-decisions-why-weakness-leads-to-aggression>.
} 
Eurasian Economic Union was framed more as a gain. Therefore, the Euromaidan and the revolution in Ukraine was threatening Putin's previous accomplishments. ${ }^{43}$

Indeed, in the context of invading Crimea, and particularly with regard to starting the operation in Eastern Ukraine, President Putin appears as a risk-taker. Yet, in his subsequent behaviour vis-à-vis Ukraine, he became less inclined towards immediate risky operations, such as an open military operation against Kiev or actively promoting the separatism of Novorossiya. Instead, he has chosen to conduct a covert proxy war there. The readiness to take risks at the beginning of the crisis could be explained by his fear of a loss, while the growing risk averseness in the course of the crisis would be caused, following the logic of prospect theory, by his willingness to defend his initial victories, that is, the annexation of Crimea and the ability to control the future of Ukraine through proxies in Donbas. Any risk-taking could easily transform these victories into major defeats, both domestically and internationally.

\section{Changing operational code?}

As already noted, psychological approaches suffer from a serious methodological setback similar to the bureaucratic politics approach - in that it is very difficult to obtain any direct evidence about the psychological reasoning or sub-conscious motivation of a decision-maker. However, approaches such as belief systems, worldviews, cognitive maps, and so forth have resolved this problem by resorting to public speeches and other similar available data, which can then become an object of content analysis or similar techniques. Before constructivism, these approaches were indeed considered rather progressive as they were apt to challenge the more traditional realist approaches by adding an ideational dimension to the analysis. ${ }^{44}$ The study of belief systems in particular became a rather popular trend in the study of Soviet foreign policy, as part of the older "ideological school". ${ }^{45}$

One application of this trend is the study of operational codes, which might also be considered "more psychological" than research on belief systems or ideology as it focuses on the

\footnotetext{
${ }^{43}$ See e.g. Bukkvoll, op. cit., p. 278.

${ }^{44}$ Ole Holsti, "The Belief System and National Images: A Case Study", Journal of Conflict Resolution, Vol. 6 (1962), pp. 244-252; Ole Holsti, "Cognitive Dynamics and Images of the Enemy", Journal of International Affairs, Vol. 21, No 1 (1967), pp. 16-39; Richard Little and Steve Smith, Belief Systems and International Relations (UK: Basil Blackwell Ltd, 1988).

${ }^{45}$ Margot Light, "Belief Systems and Soviet Foreign Policy", in Richard Little and Steve Smith, Belief Systems and International Relations (UK: Basil Blackwell Ltd., 1988), pp. 109-126; Douglas Blum, "The Soviet Foreign Policy Belief System: Beliefs Politics and Foreign Policy Outcomes", International Studies Quarterly, Vol. 37 (1993), pp. 373-394.
} 
worldviews of individuals or small groups. The concept was coined by Nathan Leites in the 1950s when he studied the operational code of the Bolsheviks, especially that of Lenin and Stalin. ${ }^{46}$ He concluded that this code included such political maxims as pushing to the limits; engaging in pursuit of an opponent who begins to retreat or make concessions, but knowing when to stop; acting when ready; refusing to be provoked; and agreeing to temporary concessions while always keeping the basic conflict and the ultimate victory in mind.

In a sense, the notions or rules are as much about the Russian character as they are about the Bolshevik character, because in addition to references to Bolshevik texts, Leites also used examples from classical Russian literature. Leites believed that in many cases it was only in Russian literature that one could find "a clear and vivid description of the feelings and the moral sentiments which are opposed, or continued, in Bolshevik beliefs". ${ }^{47}$ For the most part, the Bolsheviks, Leites claims, consciously tried to avoid typically irrational or harmful Russian behaviour. For instance, it is stated that the Bolshevik operational code denies - in opposition to the traditional Russian intelligentsia's tendency to stress sincerity - the idea that the truth should be observed in public statements; instead, any communication should be orientated on the basis of impact only. ${ }^{48}$ A real Bolshevik must also, unlike Russians typically do, "avoid the servitude and annihilation which follows from a lack of control over his feelings. He must be able to interfere with, release, and simulate emotions". ${ }^{49}$

Leites' sophisticated approach is difficult to replicate or apply to other countries and political leaders. It is partly for this reason that it was largely "neglected", as Alexander George put it, when he attempted to popularise the approach. ${ }^{50}$ George's major contribution was his development of the operational code concept into clear-cut research questions, divided into five "philosophical" questions, dealing with the nature of reality, and five "instrumental" questions of a more concrete or operational nature.

\footnotetext{
${ }^{46}$ Nathan Leites, The Operational Code of the Politburo (New York: McGraw-Hill, 1951); Nathan Leites, The Study of Bolshevism (Chicago, IL: The Free Press, 1953).

${ }^{47}$ Ibid. p. 21.

${ }^{48}$ Ibid. p. 121.

49 Ibid. p. 208.

${ }^{50}$ Alexander L. George, "The 'Operational Code': A Neglected Approach to the Study of Political Leaders and Decision-Making”, International Studies Quarterly, Vol. 13 (1969), pp. 190-222; see also Stephan G. Walker, "The Evolution of Operational Code Analysis", Political Psychology, Vol. 11, No 2 (1990), pp. 403-418 and Stephan G. Walker, "Operational Code Analysis as a Scientific Research Program: A Cautionary Tale", in Colin Elman and Miriam Fendius Elman (eds.), Progress in International Relations Theory: Appraising the Field (Boston: The MIT Press, 2003).
} 
Suffice it to say that Putin is Russian, but surely not a Bolshevik. Yet, intuitively, Leites' maxims seem consistent with his behaviour. So can we decipher anything more about Putin's thinking patterns? There is at least one attempt to uncover Putin's operational code, namely Stephen Dyson's analysis written immediately after Putin took up office as President in $2000 .^{51}$ While not applying any sophisticated quantitative methodology, Dyson followed George's original methodology rather literally, using as sources of evidence Putin's personal history, his revealing interview-autobiography from 2000, the KGB's official manual, which Putin is supposed to have internalised, as well as his speeches, writings, and deeds, especially in connection with the war in Chechnya.

On this basis, Dyson concludes that Putin's behaviour is characterised by a belief in reciprocity in following norms and rules, and that he is inclined to believe in the possibility of harmonious political life. However, if he feels that others are not following the jointly agreed-upon norms and rules, he is ready to ruthlessly strike back in retaliation. An eye for an eye is his behavioural pattern. On the other hand, Putin is not willing to adapt to norms which provide no way out, and which serve to limit his freedom. He is inclined to choose political goals that are both achievable and measurable, and he works in a step-by-step fashion. All in all, Putin's world is that of both norms and anarchy, allowing both predictable and risky behaviour. Dyson concluded that "Putin is unlikely to make rash, impulsive or emotional gestures that interfere with the rationality of political exchange", but he warned that "a breakdown in cooperation will likely be bitter and long-lived" 52

Looking at Dyson's 2001 analysis fifteen years later, it seems to capture the essence of Putin's worldview, as expressed perhaps most clearly in his October 2014 Valdai speech. ${ }^{53}$ As Allison has pointed out, Russia also explains its action in the Crimean case by referring to legal frameworks and language. ${ }^{54}$ On the other hand, contemporary Russia continues the tradition of couching its basic foreign and security policy line in very rational language and in the form of formal strategies, such as the December 2014 updated version of Russia's military doctrine.

\footnotetext{
${ }^{51}$ Stephen Benedict Dyson, "Drawing Policy Implications from the 'Operational Code' of a 'New' Political Actor: Russian President Vladimir Putin”, Policy Sciences, Vol. 34, No 3-4 (2001), pp. 329-346.

52 Ibid., p. 344.

${ }^{53}$ Vladimir Putin, "Meeting of the Valdai International Discussion Club", Sochi (24 October, 2014), available at: 〈http://en.kremlin.ru/events/president/news/46860>.

${ }^{54}$ Allison 2014, op. cit.
} 
As such, the operational-code type of approach does not offer any explanations as to individual decision-making situations, such as the annexation of Crimea, but rather helps in understanding Putin's specific rationality. While political leaders' operational codes can be reconstructed from public sources, and something about their expected actions and reactions in different situations can be inferred on that basis, it was originally assumed that operational codes had already been developed in childhood or early adulthood and rarely changed much in later phases of life. This assumption, however, has been challenged by the new wave of studies in operational codes that started in the late 1990s. Based on George's original two sets of questions, but now enhanced with rather sophisticated data treatment software, this research has analysed huge quantities of text, often produced before and after some kind of significant event or crisis. Taken together, the evidence thus acquired shows that the operational codes of such political figures as Lyndon B. Johnson, ${ }^{55}$ Jimmy Carter,${ }^{56}$ Bill Clinton, ${ }^{57}$ George W. Bush, ${ }^{58}$ Mao Zedong, ${ }^{59}$ Fidel Castro, and Kim Il-sung, ${ }^{60}$ have experienced a measurable change.

A noteworthy observation regarding George's two sets of questions - the first set concerning philosophical conceptions and the other more instrumental issues - is that it was in the more fundamental philosophical set where the significant changes were identified. ${ }^{61}$ This is completely at odds with the traditional perspective on foreign policy learning, according to which basic beliefs are the most durable ones, whereas policies and tactics are more subject to change. In the study of Soviet foreign policy, for instance, this had always been the mainstream

\footnotetext{
${ }^{55}$ Stephan G. Walker and Mark Schafer, "The Political Universe of Lyndon B. Johnson and His Advisors: Diagnostic and Strategic Propensities in Their Operational Codes", Political Psychology, Vol. 21, No 3 (2000), pp. 529-43.

${ }^{56}$ Stephan G. Walker, Mark Schafer and Michael D. Young, "Systematic procedures for Operational Code Analysis: Measuring and Modeling Jimmy Carter's Operational Code", International Studies Quarterly, Vol. 42, No 1 (1998), pp. 175-89.

${ }^{57}$ Mark Schafer and Scott Crichlow, "Bill Clinton's Operational Code: Assessing Source Material Bias", Political Psychology, Vol. 21, No 3 (2000), pp. 559-71.

${ }^{58}$ Jonathan Renshon, "Stability and Change in Belief Systems: The Operational Code of George W. Bush", Journal of Conflict Resolution, Vol. 52, No 6 (2008), pp. 820-849.

${ }^{59}$ Huiyun Feng, "The Operational Code of Mao Zedong: Defensive or Offensive Realist?", Security Studies, Vol. 14, No 4 (2005), pp. 637-62.

${ }^{60}$ Akan Malici and Johnna Malici, "The Operational Codes of Fidel Castro and Kim II Sung: The Last Cold Warriors?", Political Psychology, Vol. 26, No 3 (2005), pp. 387-412.

${ }^{61}$ Renhson, op. cit.
} 
view. ${ }^{62}$ Instead, the latest research suggests that when the fundamental beliefs of policy-makers change, their modus operandi remains largely unchanged.

If the operational code undergoes a significant change, however, one faces the puzzle of whether the concept is merely an analytical descriptive tool or whether it can also explain and predict the foreign policy decisions of leaders. Was Putin the same in 2014 as he was in 2000 ? Indeed, there used to be a discussion about Putin I and Putin II, that is, the difference between his foreign policies during the first and second presidential terms. Andrei Tsygankov, for instance, described Putin I in terms of his perceived world as "terrorism and economic competition", and in terms of Russia's national interests as "cooperation with the West". ${ }^{63}$ However, Putin II's perceived world was based on the failure of genuine partnership with the West and characterised as "US unilateralism", whereas Russia's national interests in this context would have been to demonstrate "assertiveness". Dmitry Medvedev's presidential term again changed the foreign policy course towards cooperation ("reset"), his perception of the world being "opportunities for economic cooperation" and national interests duly defined as "alliances for modernisation". While some prefer to label Medvedev's term, during which Putin served as Prime Minister, as Putin III, all the analyses of Putin's policies and beliefs identify change over time. ${ }^{64}$ This has naturally led to speculation about a more ideological, nationalist Putin IV.

In any event, even the best-informed Russian analysts failed to anticipate the major change that the Ukrainian crisis produced. This might be interpreted in such a way that while a certain reorientation towards more anti-Western foreign policy occurred immediately after Putin began his third term as president in May 2012, the Ukrainian crisis - the failure of his efforts to stop Ukraine's association with the EU, the Euromaidan movement, the collapse of the Viktor Yanukovych regime and his fleeing the country - was an unexpected catalyst for the Russian leadership. The documentary broadcast one year after the event, in which Putin disclosed the decision-making related to the annexation of Crimea, was interpreted by some Russian political

\footnotetext{
62 Jan F. Triska, "Model for Study of Soviet Foreign Policy", The American Political Science Review, Vol. LII, No 1 (1958), pp. 64-83; Philipp E. Tetlock, "Learning in U.S. and Soviet Foreign Policy", in George W. Breslauer and Philip K. Tetlock, Learning in U.S. and Soviet Foreign Policy (Boulder, CO: Westview, 1991). ${ }^{63}$ Andrei Tsygankov, Russia's Foreign Policy: Change and Continuity in National Identity, 3rd Ed. (Lanham, MA: Rowman \& Littlefield, 2013), p. 236.

${ }^{64}$ Dmitri Trenin (ed.), Russia on the Move (Moscow: Carnegie Endowment for International Peace, 2012), available at: 〈http://carnegieendowment.org/files/russia_on_the_move.pdf $>$; Elena Shestopal, New Trends in Russian Political Mentality: Putin 3.0 (Lanham, MA, Lexington Books, 2016).
} 
analysts as bearing the hallmarks of a rather impulsive decision, triggered by the feeling of betrayal and reinforced by Putin's contempt of Western political leaders who did not, in his view, take Russia's interests and Russia's leader seriously enough. ${ }^{65}$

Operational code analysis cannot, of course, fully explain Russia's or Putin's decision to invade the Crimean Peninsula. But one could argue that without the change in Putin's answers to the "philosophical questions", one could hardly understand the decision to violate the sovereignty principle that was rooted in Putin's legalistic worldview. Indeed, the proposal in the current operational code literature that the fundamental ideas of a political leader are more susceptible to change than instrumental beliefs could be supported by some evidence in Putin's case. His fundamental beliefs changed from the possibility of cautious pragmatic cooperation and harmony with the West, based on the balance of power and sovereignty, towards proclaiming a much more ideologised antagonism. ${ }^{66}$ But his operative approach towards Ukraine, when he had decided to act, was fundamentally the same as his treatment of Chechnya in 1999/the early 2000s and Georgia in 2008 despite the greater risks in the Ukrainian case.

\section{A childhood trauma?}

So-called psychological profiling is commonplace in diplomatic reports, intelligence services and everyday journalism. ${ }^{67}$ Indeed, the fact that individuals have different psychological characteristics is not something that rationalist-oriented analysts would dispute. Henry Kissinger, a personal acquaintance of Putin, wrote a brief psychological profile of Vladimir Putin back in the early 2000s, which reads as follows:

Unlike his predecessor [Boris Yeltsin], who cut his political teeth in the power struggles of the Communist Party, Putin emerged from the world of the secret police. Advancement in that shadowy world presupposes a strong nationalist commitment and a cool, analytical streak. It leads to a foreign policy comparable to that during the tsarist centuries, grounding popular support in a sense of Russian mission and seeking to dominate neighbors where they cannot be subjugated. With respect to other powers, it involves a

\footnotetext{
${ }^{65}$ Danila Gal'perovich, "Eksperty: reshenie Putina anneksirovat' Krym bylo impul'sivnym”, Golos Ameriki (10 March, 2015), available at: 〈http://www.golos-ameriki.ru/content/dg-putin-crimea-experts/2674973.html>.

${ }^{66}$ Galeotti and Bowen, op. cit., cf. Putin's own account in Putin, "Meeting of the Valdai International Discussion Club", op. cit.

${ }^{67}$ Jerold Post, (ed.), The Psychological Assessment of Political Leaders (Ann Arbor: The University of Michigan Press, 2003).
} 
combination of pressures and inducements, the proportion between which is reached by careful, patient, and cautious manipulations of the balance of power. ${ }^{68}$

However, should one employ psychological profiling, one would need to dig deeper than Kissinger. In the study of history, this approach is usually called psychohistory. ${ }^{69}$ To be sure, psychohistory is itself such a multifaceted approach that whole books have been written about its internal differences. There is no single uniform theory or methodology; some authors have applied psychoanalysis, some medical analysis, whereas others base their arguments on everyday psychology. In Soviet studies, Joseph Stalin, not surprisingly, has been a fruitful target of this type of approach, practised most notably by Robert C. Tucker. From this viewpoint, Stalin's general political behaviour was explained by his personality, rooted in the violent experiences of his childhood, which - so the argument went - gave rise to his narcissistic cult of personality and era of the Terror, mirroring his inner conflicts and selfhatred. $^{70}$

Putin's psychology is a constant theme in popular literature and nonscientific articles, stemming from the assumption that when normal democratic political institutions do not function and the country is led by an authoritarian leader, then "one cannot understand Russia's politics without psychology". ${ }^{71}$ At the same time, however, one hardly knows how decisions are arrived at because Putin's rise to power "sharply increased the level of secrecy in the work of the authorities". ${ }^{72}$ Given Putin's power and the cult surrounding him, it is no wonder that also scholars with diverse background have attempted to provide a psychological profile of Putin's personality. Yet in the various accounts of Putin's personality, there is no prevailing view with regard to Putin as a risk-taker: some see Putin as a personality willing to take risks, while others emphasise that he is very careful in his moves. ${ }^{73}$

\footnotetext{
${ }^{68}$ Henry Kissinger, Does America Need a Foreign Policy? Toward a Diplomacy for the 21 st Century (New York: Simon \& Schuster, 2001), p. 75.

${ }^{69}$ Peter Loewenberg, "Psychoanalytic Models of History: Freud and After", in William McKinley Runyan, Psychology and Historical Interpretation (Oxford: Oxford University Press, 1988), pp. 126-156.

${ }^{70}$ Robert C. Tucker, Stalin as Revolutionary, 1879-1929: A Study in History and Personality (New York: Norton, 1973); Daniel Rancour-Laferriere, The Mind of Stalin: A Psychoanalytical Study (Ann Arbor, Mich.: Ardis, 1988); Ronald Grigor Suny, "Beyond Psychohistory: The Young Stalin in Georgia", Slavic Review, Vol. 50, No 1 (1991), pp. 48-58.

${ }^{71}$ Vasilij Blazhennyj, "Vladimir Putin: anatomija lichnosti", Novaja Gazeta (15 August, 2012), available at: <http://www.novayagazeta.ru/politics/53963.html>.

72 E. B. Zjuzina, "Prezidentskoe liderstvo v Rossii: funkcional"no-psihologicheskie osobennosti", Vestnik VGU, Serija: Istorija, Politologija. Sociologija (2015), No. 1, pp. 70-75, here p. 72.

${ }^{73}$ Bukkvoll, op. cit. pp. 277-278.
} 
Drawing on psychoanalysis, Juhani Ihanus describes how Putin's life was, from an early age, characterised by fighting his way forward. ${ }^{74}$ Putin did not receive much support from his parents, who showed little "Vova" no demonstrable affection. The child's physical stress and frustration led him to suppress his emotions as there was no way to vent them. Putin's adult character was subsequently born of a fear of feelings and affection, a kind of encapsulation, which was reflected in his personal identity, and which shaped his future actions in society. Putin's full identity was formed in the axis of this rather prosaic personal tragedy and in the pressure of the totalitarian social system, finally finding a balance in the role of a secret service agent. However, surprised by his sudden success, when he became Prime Minister and then President, and following the first political struggles, Putin's character changed - to quote Ihanus - to that of "a rational terminator", who despised the enemies of the state. At first, it was the Chechens in particular who were punished for their attempt to destroy the state. Putin then went on to restore the glory of the Soviet security service, the KGB, hanging a picture of his idol, Yuri Andropov, the former KGB director and subsequent party leader, on his wall, and taking steps to recreate a strong state. Putin, looking inside himself, instinctively felt that only hard top-down discipline could bring salvation to the Russian people and mitigate their collective internal contradictions and restlessness; a totalitarian psyche, which, when confronted with freedom, turned to self-accusations and shame. That conflict could be settled by directing this shame towards external parties, and instilling blind confidence in the state executive. Personally, Putin concealed his internal feelings of shame by resorting to anger and rage, hiding all signs of weakness, resorting to force as the only way to avoid being insulted and humiliated. He arranged his features into a frozen expression, thus involuntarily defending his vulnerable feelings, which he was incapable of expressing. When he became a public figure, his media advisors had difficulty teaching him to express some kind of contrived semblance of a smile. Ultimately, Putin suppressed his internal conflicts with narcissism, which is typical of all dictators. It led to wholesale dominance and the inevitable creation of Putinism, casting the environment and society at large according to his own image. But before long, an awareness of his own aging and eventually demise came into the picture. This feeling of weakness and

\footnotetext{
${ }^{74}$ Juhani Ihanus, "Profiling Russian Leaders from a Psychohistorical and a Psychobiographical Perspective", in Ofer Feldman and Linda O. Valenty (eds.), Profiling Political Leaders: Cross-Cultural Studies of Personality and Behavior (Westport, CO: Praeger, 2001), pp. 129-148; Juhani Ihanus, "Putin the Aging Terminator: Psychohistorical and Psychopolitical Notes", The Journal of Psychohistory, Vol. 35, No 3 (2008), pp. 240-269; Juhani Ihanus, "Putin and Medvedev: Double Leadership in Russia", The Journal of Psychohistory, Vol. 38, No 3 (2011), pp. 251-284; Juhani Ihanus "Putin’s Macho Pose: On Masculinity and Psychopolitics", The Journal of Psychohistory, Vol. 42, No 2 (2014), pp. 110-129.
} 
inevitable mortality - as Ihanus predicted in 2008 before the Georgian war - would eventually shred the internal protective veil, and would be likely to lead to aggressive and sadistic behaviour.

In the same spirit, in a lengthy interview, the Swiss psychoanalyst Philipp Jaffe expressed the view that Putin's actions as president are characterised by some kind of childhood trauma related to weakness. ${ }^{75}$ He claimed that from the perspective of a professional psychoanalyst utilising psychobiography as a method, it was not necessary to personally know the subject under analysis; close investigation of what was known about the person's biography, personality, and professional interactions would suffice. What was noteworthy in his assessment was that Putin takes any criticism against Russia personally, and tries to retaliate with force. "All of this is due to his childhood," Jaffe claims. "He has to prove that it is better not to engage in a dispute with him. When other children shove him, he shows his physical strength in no uncertain terms. His driving force is to see to it that no one can ever control him." According to Jaffe, Putin has transferred these personal characteristics into his political activities, which is why he has achieved almost absolute power in Russia. The psychoanalyst sees Putin as a very intelligent person, who nonetheless suffers from a number of complexes. Upon reaching a position of relatively unlimited power, such a person may develop several other syndromes.

The notion of "childhood trauma" and "emotional chaos" producing a narcissistic and bullying personality is reiterated in many journalistic accounts. According to these stories, Putin apparently grew up feeling that he had some kind of internal defect, harbouring thoughts that there was something about himself that was damaged and shameful. So he developed a defensive identity to hide his subconscious shame and to prove that he was a winner instead. ${ }^{76}$ Just what this trauma was exactly remains unclear, but in Putin's unauthorised biographies it is always emphasised how his point of departure was one of poverty and physical weakness, and how he had to fight his way up amongst the thugs that populated the courtyard where he used to hang out as a child:

\footnotetext{
${ }^{75}$ Yelena Servettaz, "Psiholokicheskiy potret Putina: 'Putin perezhil serhozhnuyu traumu v detsve", RFI (29 September 2014), available at: 〈http://ru.rfi.fr/ukraina/20140929-psikhologicheskii-portret-putina-putinperezhil-sereznuyu-travmu-v-detstve/>.

${ }^{76}$ Joseph Burgo, "Vladimir Putin, Narcissist? How the psychology of narcissism might offer insight on the Russian leader." The Atlantic (15 April, 2014), available at: <http://www.theatlantic.com/health/archive/2014/04/vladimir-putin-narcissist/360544/>.
} 
Putin, younger than the thugs and slight of build, tried to hold his own with them. 'If anyone ever insulted him in anyway', his friend recalled, 'Volodya would immediately jump on the guy, scratch him, bite him, rip his hair out by the clump - do anything at all never to allow anyone to humiliate him in any way'. ${ }^{77}$

It is well documented that Putin started training in martial arts, first boxing and then Sambo, a Soviet-style judo, so that he could handle himself even better on the street. The biographical evidence suggests that his growing physical prowess, later supplemented with a junior position in the most feared institution in the Soviet Union, the KGB, made him no less impulsive or violent, but certainly much calmer and self-confident when he encountered physically challenging situations. ${ }^{78}$

Putin has duly managed to turn his tough childhood experiences to his advantage, indeed into a mythology, emphasising his antisocial characteristics. In his interview-based autobiography, he boasted thus:

Q: Why did you not get inducted into the Pioneer Organization until sixth grade? Were things really so bad?

Putin: Of course, I was a hooligan, not a Pioneer.

Q: Are you trying to be modest?

Putin: Now you are insulting me? I was indeed a thug. ${ }^{79}$

In October 2015, in the final session of the so-called Valdai discussions, Putin publically informed the audience (referring to Syria): "Even 50 years ago, the streets of Leningrad taught me one thing: if a fight is inevitable, go and fight first." This typical Putinesque quote quickly hit the headlines worldwide, and NATO's official commentators did not hesitate to tweet it.

\footnotetext{
${ }^{77}$ Masha Gessen, The Man without a Face: The Unlikely Rise of Vladimir Putin (New York: Riverhead Books, 2012), p. 38.

${ }^{78}$ Ibid.

${ }^{79}$ N. Gevorkyan, A. Kolesnikov and N. Timakova, Ot pervogo litsa. Razgovory s Vladimirom Putinym (Moscow: Vagrius, 2000), p. 19.
} 
Perhaps the best-known Western analysts of Putin's personality, Fiona Hill and Clifford G. Gaddy, claim that the Russian leader suffers from a "personality disorder" caused by the fact that he actually has several identities, which are in conflict with each other. ${ }^{80}$ Indeed, many in the West tend to see Putin's personality in a rather negative light. He has been called a "highdominance introvert", with a mindset characterised by a tendency to view the world as a conflictual zero-sum game, and reliant on an expansionist orientation in foreign affairs, ${ }^{81}$ or that "contempt" is the key to his psychological profile. ${ }^{82}$ Some journalists have noted a peculiar trait in that he does not respect other people's property, but thinks instead that everything is his for the taking. ${ }^{83}$ A simple google search of "Is Putin a psychopath?" returns hundreds of thousands of hits. Among them is a comment by Latvia's former president, Vaira ViḳeFreiberga, who was trained as a clinical psychologist and worked in that field for many years. She however was talking of the whole of Russia when arguing that, "We share a common border with a psychopathic power, which lives by useless and dangerous illusions [...] One mustn't be sentimental about the mysterious Russian soul; one must be alert when one lives next to a psychopath". ${ }^{84}$

Moreover, it has also been suggested that Putin has "an autistic disorder which affects all of his decisions". This was reportedly the outcome of a Pentagon-sponsored study conducted by Brenda Connors at the US Naval War College in 2008. ${ }^{85}$ Although the experts were not able to clinically confirm that Putin suffers from Asperger's syndrome in the absence of a brain scan, they found symptoms that were similar: for example difficulties staying calm in social settings and low thresholds to be reactive. In another study, neurologists have discussed the reason for Putin's “virtually absent right arm swing". While they rejected the diagnosis of Parkinson's

\footnotetext{
${ }^{80}$ Fiona Hill and Clifford G. Gaddy, "Putin Personality Disorder: Russia's president may like to look tough, but he's weaker than you think." Foreign Policy (15 February 2013), available at: 〈http://foreignpolicy.com/2013/02/15/putin-personality-disorder/>.

${ }^{81}$ Aubrey Immelmann, "The Personality Profile of Russian President Vladimir Vladimirovich Putin” (n.d.) $<$ http://www.immelman.us/news/russia-threat-assessment-psychological-profile-of-vladimir-putin/> .

${ }^{82}$ Ian H. Robertson, “The Danger That Lurks Inside Vladimir Putin's Brain”, Psychology Today (17 March, 2014), available at: <https://www.psychologytoday.com/blog/the-winner-effect/201403/the-danger-lurksinside-vladimir-putins-brain>.

${ }^{83}$ Ian H Robertson, "Inside the mind of Vladimir Putin", The Telegraph (24 February, 2015), available at: $<$ http://www.telegraph.co.uk/news/worldnews/europe/ukraine/11431850/Inside-the-mind-of-VladimirPutin.html>.

84 “Kremlin - a 'psychopathic power with dangerous illusions', Vike-Freiberga says", Euromaidan Press (17 September, 2015), available at: <http://euromaidanpress.com/2015/09/17/kremlin-a-psychopathic-power-withdangerous-illusions-vike-freiberga-says/>.

${ }^{85}$ Ray Locker, "Pentagon 2008 Study Claims Putin Has Asperger's Syndrome”, USA Today (February 4, 2015), available at: $\langle$ http://www.usatoday.com/story/news/politics/2015/02/04/putin-aspergers-syndrome-studypentagon/22855927/>.
} 
disease or a preclinical stage of the disease, as Putin's motor skills are otherwise excellent, they suggest that this so-called "gunslinger's gait" is a behavioural adaptation resulting from Putin's intelligence training. The fact that Prime Minister Dmitry Medvedev walks in the same way, without having a military or intelligence background, is duly explained by the suggestion that Medvedev has learned to imitate his boss, an imitation phenomenon that has parallels in the neurological field in cases of a disorder known as hyperekplexia. ${ }^{86}$

To sum up, the psycho-historical approach and other attempts to define Putin's personality, in addition to their theoretical and methodological problems, are rather speculative due to the nature of the sources they rely upon, and can therefore often reflect more the imagination and biases of the theorist than the object. The fact that the Western mass media and social media are awash with such interpretations contributes to the notion that the West is demonising Putin, with suggestions that he is a typical narcissist, suffers from a severe psychological disorder rooted in his childhood, and had a family life marred by trauma and emotional chaos. The sources underpinning such analyses are bound to be mainly second-hand and indirect, and most likely anecdotal. They are seldom nuanced enough to account for any variation and are often part of the psychological warfare in a conflict situation. Yet such narratives may challenge us to think more systematically about possible character traits. If we trust these accounts, the tough overall attitude of Russia's foreign policy and its impulsivity can, at times, be seen as compatible with the general perception of Putin's personality.

While psychohistorical narratives and psychological profiling are rather far removed from any credible explanation of Russia's decision-making, we should nevertheless be ready to widen foreign policy analysis theoretically to include the possibility of such factors. We should also pose a counterfactual question: Would Russia have invaded Crimea under a different president with a different psychological profile? Counterfactual theories of causation take as their point of departure the basic idea that the meaning of causal claims can be explained in the form of "If A had not occurred, C would not have occurred". ${ }^{87}$ While there are several versions within this debate, it is difficult to form a strong contrafactual for Putin's role in the Crimean case. Even if Putin's psychological characteristics were part of the explanation, they would not

\footnotetext{
${ }^{86}$ Rui Araújo et al., "Gunslinger's gait: a new cause of unilaterally reduced arm swing”, BMJ (2015); 351:h6141, available at: 〈http://www.bmj.com/content/351/bmj.h6141〉.

87 Peter Menzies, 'Counterfactual Theories of Causation', The Stanford Encyclopedia of Philosophy (Spring 2014 Edition), Edward N. Zalta (ed.). <http://plato.stanford.edu/archives/spr2014/entries/causationcounterfactual/>. With regard to a counterfactional see Harvey ee Harvey Iraq
} 
provide sufficient reasons for Russia's annexation of Crimea. It is possible that had the circumstances been different, the annexation would not have occurred under Putin, or had there been another president, Russia would have reacted to the developments in Ukraine differently. Such an argument would contest the tenet of Mearsheimerian realism according to which any rational Russian statesman would have behaved similarly towards the external threat, but in all fairness to neorealism for example Kenneth Waltz would not make such a claim. By contrast, in his Man, State, and War he made it clear that the structure of the international system does not directly cause one state to attack another, but psychological factors can trigger a particular war. $^{88}$

\section{An “angry, angry man"?}

Was the annexation of Crimea an impulsive and angry reaction to the revolution in Kiev rather than a long-planned territorial expansion? The question of the role of emotions in Russian foreign policy decision-making is not a new theme, but it has not been properly integrated into academic research. One reason for this is that emotions are often seen as pejorative and contributing to.conjecture about a special Russian character or abnormality. For example, Dmitri Trenin and Bobo Lo have argued (referring more to Western descriptions of Yeltsin than of Putin) that "there exists an implicit assumption that Russian policy-makers behave inherently less rationally than their foreign counterparts, being driven not so much by concrete national interests as by highly subjective and even personal impulses". ${ }^{89}$ Trenin and Lo conclude that the unfortunate consequence of such arbitrary decisions about what is and is not rational is that Russia has been transformed from an object of serious scientific enquiry into a mystical and virtually "unknowable" entity. ${ }^{90}$ Although we may not obtain definitive answers, we should nevertheless consider how the role of emotions in Russian foreign policy might be formulated and how meaningful research into the subject can be conducted.

Two opposing stereotypes of Russians in general, and of Russian political leaders in particular, have a long pedigree in the literature as well as in contemporary narratives about Russians. ${ }^{91}$ One such stereotype is the cold-blooded, calculating chess-player with a long-term plan who contemplates every move rationally. Then there is the emotional type who reacts impulsively;

\footnotetext{
${ }^{88}$ Waltz, Man, State and War.

${ }^{89}$ Dmitri Trenin and Bobo Lo, The Landscape of Russian Foreign Policy-Making (Moscow: Carnegie Endowment for International Peace, 2005), p. 8.

90 Ibid.

${ }^{91}$ Ronald Hingley, The Russian Mind (London: Bodley Head, 1978).
} 
guided by his feelings, he does everything to excess, and lives in the moment. In Russian politics, emotions are typically attributed to some leaders more than to others. Whereas President Boris Yeltsin was often characterised as an emotional figure, Putin has typically been regarded as his opposite: an officer with a KGB background who only serves the Russian national interest and does not reveal anything about his inner life - the "man without a face". 92 In Leites' terms, he would be a perfect Bolshevik, someone who does not allow himself to be swayed by typical Russian sentimentalism.

There are numerous examples that support this view of Putin as a calculating, rational thinker. In his Munich speech in 2007, which some have dubbed the back-to-the-Cold-War speech, Putin expressed himself in almost game-theoretical terms: "I would not want anyone to suspect any aggressive intentions on our part. But the system of international relations is just like mathematics. There are no personal dimensions". ${ }^{93}$ Moreover, in December 2015 he categorically stated that, "Emotions are inevitable, but they should not affect the quality of decisions, because these decisions are in the interests of millions of people, millions of Russian citizens". ${ }^{94}$ In an interview in June 2015, Putin emphasised that Russia's logic is that of the security dilemma, that is, a reaction against external threats: "Everything we do is just a response to the threats emerging against us. Besides, what we do is limited in scope and scale, but is, however, sufficient to ensure Russia's security". 95

In journalistic accounts, references to Putin's emotions, or rather the lack thereof, are commonplace. For example, when Putin had to address the Kursk submarine tragedy at the beginning of his presidential career, he was seen as being emotionally cold. It is almost as if he prefers that image. When he was seen in tears after the 2012 presidential elections, it was due to the wind, and not his emotions, explained Putin's spokesman. Yet Putin often expressed his emotions when issues related to terrorism in the North Caucasus were discussed. Indeed, the principal emotion attributed to Putin is anger. For example, Richard Stengel, the managing editor of Time magazine described Putin as an "angry, angry man" when announcing that he

\footnotetext{
92 Gessen, op. cit.

${ }^{93}$ Vladimir Putin, "Speech and the Following Discussion at the Munich Conference on Security Policy", Munich (10 February, 2007), available at: <http://archive.kremlin.ru/eng/speeches/2007/02/10/0138 type82912type82914type82917type84779_118123.shtml>.

94 'Vladimir Putin: emocii ne dolzhny vlijat' na reshenija.' Vesti.ru (20 December 2015), available at: <http://www.vesti.ru/doc.html?id=2700196\&tid=109283 >.

95 'Russia would attack NATO only in mad person's dream - Putin,' RT, (6 June, 2015), available at: <https://www.rt.com/news/265399-putin-nato-europe-ukraine-italy/>.
} 
had been chosen as Person of the Year 2007. Others have noted that, "Putin's judo training taught him to control his emotions, but when he is angry his outbursts can be not only crude but breathtakingly acerbic". 96

Putin's emotions, as the president of Russia, cannot be understood without the social context of the extended self of Russia. Putin himself, especially when addressing a Russian audience, is reminiscent of the mythological notion of an idealistic Russian soul:

Of course, we are less pragmatic, less calculating than representatives of other peoples, and we have bigger hearts. Maybe this is a reflection of the grandeur of our country and its boundless expanses. Our people have a more generous spirit. ${ }^{97}$

Putin's hardline policy towards the West can also be seen as reflecting cultural models rather than individual impulses. ${ }^{98}$ It is difficult to say exactly how prevalent and accepted anger is as an emotion in Russian culture, but it is hardly merely an irrational sentiment. Displays of anger are quite common in Russian political and business life. Guides to business etiquette in Russia may, for example, advise: "Expect your Russian colleagues to get angry, walk out of a meeting and/or talk about ending their relationship with you in their effort to make you give more concessions during a negotiation". 99

There is a fine line between assertiveness and anger in Russia, and hence displays of anger often reflect superiority and determination, convey an image of effectiveness and can also increase a politician's domestic popularity. ${ }^{100}$ It can be suggested that Putin's emotional outbursts may have helped achieve some foreign policy goals. For example, his speech at the Munich security conference in 2007, in which he sharply criticised the United States and its planned missile defence system, received particular attention because of its angry tone. The speech was important because Putin was able to shift the agenda from democracy development in Russia to military strategic issues between the West and Russia. Russians themselves,

\footnotetext{
${ }^{96}$ Paul Starobin, "The Accidental Autocrat", The Atlantic (March 2005), available at: $<$ http://www.theatlantic.com/magazine/archive/2005/03/the-accidental-autocrat/303725/>.

${ }_{97}$ Vladimir Putin, "Direct line with Vladimir Putin", Moscow (7 April 2014), available at: <http://eng.kremlin.ru/news/7034>.

${ }^{98}$ Hans Adomeit, "Putins Paukenschläge", Internationale Politik, Vol. 63, No 2 (2008), pp. 53-62.

99 "Russia - A Formal Approach", UnitedSucces (28 June, 2013), available at:

$\langle$ http://www.unitedsucces.com/cultural/338>.

${ }^{100}$ Mark Katz, “Assertive but Alone”, The World Today (November 2007), pp. 29-30.
} 
however, have claimed that Putin's speech in Munich was "calculated" and not "emotional", although it may have sounded so. ${ }^{101}$ As Todd Hall notes, it is typical for political actors themselves to deny that they were driven by emotions, even when the evidence suggests that they were. ${ }^{102}$

Anger is typically seen as an emotion conducive to inflicting harm on the other and motivating costly punishments. ${ }^{103}$ It is nonetheless important to remember that anger is not merely a negative emotion that always results in violent behaviour, but that it can also be seen as a constructive emotion aimed at addressing and rectifying wrongdoings rather than dissolving a relationship. ${ }^{104}$ Even when aggression is caused by anger, often its point is not so much to hurt the other as to send a message about a perceived injustice. ${ }^{105}$ Moreover, anger is not simply an impulsive emotional outburst, but can oftentimes be a long-lasting disposition. ${ }^{106}$ It can explain the fixation of the angered party on an issue even when the chances of influencing the issue have passed. Another action tendency found in psychological studies is that "people feeling angry had more optimistic risk assessments than did people feeling fear". ${ }^{107}$

The source of anger is often related to offences against identity or violations of key rights and moral codes. Thus Russia has reacted angrily to NATO expansion, the Kosovo war, or missile defence that are not simply security issues but heavily loaded with the quest for underlying principles and norms, and Russia's desire to regain status as a great power on a par with the West. ${ }^{108}$ The circumstantial evidence that Russian decision-makers took offence, and that the Ukrainian crisis constituted not only a potential threat but the 'unconstitutional revolution' was seen as a breach of fundamental norms as well as a direct insult to Russia's identity as a great

101 “RT Guest: Dmitry Peskov", Russia Today (9 June 2007), available at:

<http://www.russiatoday.ru/guests/detail/25>.

102 Todd Hall "We Will not Swallow this Bitter Fruit: Theorizing a Diplomacy of Anger", Security Studies, Vol. 20, No 4 (2011), pp. 521-555.

${ }^{103}$ See e.g. Elise Seip, Wilco Dijk and Mark Rottelveel, 'Anger Motivates Costly Punishment of Unfair Behavior’, Motivation \& Emotion, Vol. 38 No 4, (2016) pp. 578-588 .

${ }^{104}$ Robert Solomon, True to Our Feelings: What Our Emotions Are Really Telling Us (Oxford: Oxford University Press, 2007), p. 18.

105 Janne van Doorn, Marcel Zeelenberg and Seger Breugelmans, "Anger and Prosocial Behavior", Emotion Review, Vol. 6, No 3 (2014), pp. 261-268.

${ }^{106}$ See e.g. Richard Wollheim, On the Emotions (New Haven (CT): Yale University Press, 1999).

107 Jennifer R. Dunn and Maurice E. Schweitzer, "Feeling and Believing: The Influence of Emotion on Trust", Journal of Personality and Social Psychology, Vol. 88, No. 5 (2005), p. 738.

${ }^{108}$ Regina Heller, "Subjectivity Matters: Reconsidering Russia's Relations with the West", in Roger E. Kanet and Maria Raquel Freire (eds.), Russia and European Security (Dordrecht: Republic of Letters Press, 2012); Regina Heller, "Russia's Quest for Respect in the International Conflict Management in Kosovo", Communist and Post-Communist Studies, Vol. 47, No 3-4 (2014), pp. 333-343. 
power, is overwhelming. It is possible to support this interpretation both on the basis of public statements and appearances. For instance, in his Crimea speech on 18 March 2014, when referring to the West, Putin claimed that:

[...] they have lied to us many times, made decisions behind our backs, placed us before an accomplished fact. [...] They are constantly trying to sweep us into a corner because we have an independent position, because we maintain it and because we call things like they are and do not engage in hypocrisy. But there is a limit to everything. And with Ukraine, our western partners have crossed the line, playing the bear and acting irresponsibly and unprofessionally. ${ }^{109}$

Hence, there is reason to believe that anger has been a genuinely important element in Russian foreign policy in the Ukrainian conflict. As Tsygankov claims, "the support for Crimea and hostility toward the Ukrainian revolution must be understood as a reflective reaction to what the Kremlin views as neglect of Russia's values and interests and unjust treatment by the West". ${ }^{110}$ It is clear to see that there have been subjective grounds for Russia to be angry about the behaviour of the West in relation to the crisis in Ukraine, and Russian foreign policy behaviour also seemed to follow the logic of anger. The issue was at the heart of Russian identity, as well as Putin's sense of justice. Hence Russia reacted in line with action tendencies associated with anger by using sharp language, inflicting harm, and even instigating a hazardous, violent campaign.

\section{Conclusions}

This article has considered a range of psychological theories applicable to the study of Russian foreign policy, focusing in particular on Russia's decision to invade and then annex the Crimean Peninsula. The chosen approach emphasises the specific role and character of the key decision-maker in the case, President Putin, but psychological approaches should not be equated with individual-level explanations. The relevant information and data available on the current decision-making situation are not abundant enough for the psychological explanations and interpretations discussed above to be validated beyond reasonable doubt, and unfortunately

\footnotetext{
${ }^{109}$ Vladimir Putin, “Address by President of the Russian Federation”, Moscow (18 March, 2014), available at: <http://eng.kremlin.ru/news/6889>.

${ }^{110}$ Tsygankov, "Vladimir Putin's Last Stand: the Sources of Russia’s Ukraine Policy”, op. cit., p. 297.
} 
it is unlikely that much new "hard evidence" could be presented in the near future. However, realist, liberal and constructivist theories all contain assumptions about decision-making that they cannot prove with much concrete evidence when providing explanations for particular cases. Although psychological approaches entail methodological and evidence-related problems, there are both practical and theoretical reasons for integrating them more effectively into the academic research on Russian (or any nation's) foreign policy.

Psychological approaches can generate new research questions and resolve some of the existing puzzles in the analysis of foreign policy. While it is difficult to come up with a definitive explanation based solely on psychology, it is possible to advance partial explanations of Russia's behaviour and validate these to the extent that they are plausible in the light of the available evidence consisting of the circumstantial knowledge of the decision-making situation and congruence with the policy outcomes. While external power relations, domestic politics and national identities cannot be omitted as structural conditions having causal impact, the psychological dimension of Russian foreign policy, focusing on the main decision-maker, President Vladimir Putin, can still be crucial. These psychological factors should be seen as part of the overall explanation alongside the IR grand theories. In terms of counterfactuals, we can consider the psychological factors as causal triggers of the decision in certain structural conditions, or intervening variables that explain the relationship between the independent and dependent variables, ${ }^{111}$ without which the foreign policy behaviour would be different.

Taking all of the above into account, has our approach been able to shed any light on Russia's decision to invade Ukraine and annex Crimea? Not as much as we had hoped perhaps and at least not with any certainty. Yet, the psychological approaches pass the 'hoop test': groupthink, prospect theory, the operational code and the personality of the main decision-maker, as well as situational emotions can explain some important aspects of Russian foreign policy, in particular, why the propensity to take risks in the context of the Ukraine crisis had risen. In this way, they do not hamper the intellectual effort to understand Russian foreign policy, but actually facilitate it. Nothing in realist, liberal or constructivist theories deny their possible role. Indeed, even advocates of rational choice admit that psychological approaches perform "at least as well as rational choice methods, because the former accept all the variables that the

\footnotetext{
${ }^{111}$ For instance, cf. the model in K.J. Holsti (ed.), Why Nations Realign: Foreign Policy Restructuring in the Postwar World (Boston: Allen \& Unwin, 1982).
} 
latter recognize as important in explaining a case". True, rationalists do not regard this as a sign of theoretical superiority, but rather only as proof of greater "descriptive accuracy of an individual case". ${ }^{112}$ Nevertheless, we consider that Russian foreign policy studies can pave the way for concrete research on the role of these factors in international affairs in general, without singling Russia out as a special, anomalous case.

112 James D. Morrow, "A Rational Choice Approach to International Conflict", in Alex Mintz and Nehemia Geva, (eds.), Decision-Making on War and Peace: The Cognitive-Rational Debate (Boulder, CO: Lynne Rienner Publishers, 1997), pp. 11-31, here pp. 29, 30. 